\title{
Visuality 2017: Tourism vs Heritage in a Creative City
}

\author{
VITALIJA KECIORYTE், NERIJUS STASIULIS \\ Department of Philosophy and Cultural Studies, Faculty of Creative Industries, Vilnius Gediminas Technical University, Trakų St. 1, \\ 01132 Vilnius \\ Email: vitalija.kecioryte@vgtu.It; nerijus.stasiulis@vgtu.It
}

\begin{abstract}
The article reviews the fourth international scientific conference "Visuality 2017: Tourism vs Heritage in a Creative City". The text presents the course of the conference and the ideas of the speakers which covered a variety of related topics. The conference discussed the issues that arise in the creative city in both broad theoretical and specific practical terms. For instance, theoretical analyses of practical (political, everyday) debates on dealing with the Soviet cultural heritage in the region of Eastern Europe were proposed alongside novel approaches to multimedia technologies and their role in enhancing attractiveness and approachability of the creative city. Multiple ways of turning one's being creative in a city as well as ways of seeing the creative city were discussed or suggested.
\end{abstract}

Keywords: creative city, heritage, multimedia technologies, tourism, visuality

\section{INTRODUCTION}

On 20 April 2017, Vilnius Gediminas Technical University held a Visuality conference which takes place every two years. This one was the fourth and the speakers were invited to focus on the aspects of Tourism vs Heritage in a Creative City. The scientific event was organized by the VGTU Faculty of Creative Industries.

Currently, urban policy makers must deal with a crucial contradiction between preserving heritage and promoting tourism. As some key theorists (such as Landry 2000; Florida 2015) have noticed, a creative city values cultural heritage and its visual treasures attract people (tourists). However, their short-term visits mean increasing noise, pollution and even crime and, accordingly, the city turns less attractive. The members of the conference came up with a number of considerations and proposals of dealing with this kind of contradictions. The organizers asked what visual ecology could sense of such dilemmas, how should we visualize a creative city in the face of the contradictions, which multimedia technologies are most promising with respect to solving the problems inherent to the creative city?

\section{THE ISSUES IN THE CREATIVE CITY}

The first plenary session was chaired by Luis Pinto (Portugal) and the opening presentation on "Policy of Urban Public Spaces: the Case of Vilnius' Green Bridge Sculptures" was delivered 
by Tomas Kačerauskas (VGTU). The author is usually known for his publications on creativity (Kačerauskas 2015; Kačerauskas 2014; Kačerauskas 2012) and media studies (Kačerauskas 2008). However, this presentation was related rather to his studies on visuality (Kačerauskas 2010). He started with an overview and analysis of current debates on the removal of Soviet sculptures from the Green Bridge in Vilnius as well as a description of the circumstances of their demolition, and then proceeded to consider whether the Soviet heritage should be preserved and whether it is possible to separate and protect it from the political aspect. He noted that the opponents of the removal of the sculptures comprised a "broad front" of members of the Russian-speaking community, intellectuals, members of political opposition and even certain liberals and professional humorists whereas the supporting side of the society was not lacking in variety, either, as it included volunteers, ruling politicians, "levellers" (willing to "purge" the city of luxury) and another kind of "liberals". Kačerauskas wondered whether fighting against the Soviet heritage did not serve to promote precisely the things against which one thus wishes to fight, i.e. voluntarism and disregard of the majority opinion. Does the destruction of the artistic testimonies of the Soviet reality not bring us closer to the totalitarian reality, be it in another guise?

Next, Franz Fischnaller (Accademia Albertina di Belle Arti di Torino, Italy) delivered a presentation on "Reshaping the Virtual Skin of Emotional, Creative Imagined Cities". He was emphatic that the creative city stands up as a paradigm of the economic and managerial discourse for competitive cities, places and regions. The notion of "creative city", as it is applied to cities which have built their urban strategies around notions of high culture, has increasingly become the focus of attention of cultural policy, policy makers or, more broadly, public policy. The paradigm of creative city does present a challenge for policy makers, who concern themselves not merely with the possibilities for growth but also with the redistribution of strategies including policy frameworks and regulations. The author noticed that there has been much debate on what creative cities (as places of culture which sustain economic and urban development as well as social prosperity) are imagined to be, as well as on what they actually are, with respect to their being equipped to respond to our expectations, and on how many of them are actually living up to these expectations. He concluded with the words of C. Landry that what R. Florida termed "creativity" is like rash: it has spread everywhere and everyone is in the game of creativity. Creativity has become a "mantra" of our age endowed almost exclusively with positive virtues. Cities, regions and nations - all refer to themselves as creative.

Mester Béla (Institute of Philosophy of the Research Centre for the Humanities of the Hungarian Academy of Sciences, Hungary) discussed the claim that "the national culture must come from the cities, as the Law comes from Zion (1841)". The author is known for his philosophical papers on the history of Hungarian philosophy (Petcu, Mester 2016). In the presentation of this title, the author offered an analysis of the relationships nation-city and country-capital in the region of East-Central Europe in the 19th century which was delivered in a framework of a case study. The case study dealt with the role and function of the cities and towns of Hungary in the development of the Hungarian national culture. To cut to the chase, János Hetényi in his work published in 1841 found the equilibrium between the topics of city and nation and succeeded in describing a dynamic model of the interaction between the city and its country side. But this model of the urban nation, organized by cities as cultural centres, only worked in the optimistic decades of the Hungarian Reform Era (1825-1848), and it was soon paralleled by the known elements of cultural criticism in the epochs to come, such as themes of sinful and (ethically) alien city. 
The opening part of the conference was concluded by a distant keynote speaker Algis Mickūnas (University of Ohio, USA) who spoke on "Poli-centric Consciousness and Communication". He sought to undercut the controversy of the priority of either individual or society because communicative consciousness is dialogic and it precedes both the "communal spirit" and the individual. What is more, it does not limit itself in terms of time and space and extends to include others of other times and places for the sake of synthesis of understanding. The synthesis was described by Mickūnas as the ever-present "form" or "vertical telos" required for a mutual integration of differences and even of disagreements. Mickūnas is known for his very broad scientific interests including studies of pop-culture (Mickūnas 2017), of corporeity (Mickūnas 2015), and of dialogue (Mickūnas 2016).

\section{SMART CITY AND URBAN SETTINGS}

The next segment of the conference, chaired by Ryte Žiūrienè (Lithuania), was devoted to the topic of Smart City and Urban Settings. The first to speak was Ilya Inishev (Higher School of Economics, Moscow, Russia) with his presentation "Embedded Creativity: Multisensorial Experiences in Contemporary Urban Settings". Firstly, he introduced the notion of experiential, or embedded, creativity alongside the difference between low- and high-resolution experiencing, which, accordingly, correlates with the difference between objectifying (mostly optical) and environmental (mostly haptic) modes of sensuous perception. The correlation between a type of perceptive experience and a respective type of perceived materiality was also discussed with a special regard to the urban settings understood in terms of the notion of the continuum of textured (culturalized, aestheticized) surfaces. The related conceptions of action, reflection and self-consciousness were also heeded. Secondly, the author applied his theoretical insights into the practical issue of tourism under the current conditions of creative city. He paid a particular attention to the weakening of the notion of creativity with the rise of the creative city but this weakness was, paradoxically, the considered strength. Other issues discussed were the negative role of urban branding in the light of the notion of "non-visual" tourist experiences, the necessity to devalue symbolic/ expressive contents of environmental cultural objects, non-spatial mobility, reasons and means for cultivating the multisensorial practices and the notion of travelling as a form of a multilayered cultural production drawing on the activation of some perceptual possibilities.

Akvilè Gelažiūtè, Romualdas Baušys (VGTU), and Teodor Kuhn (Slovakia) delivered a co-presentation "Smart City: Educational Movies" which dealt with the general background and functional areas of the smart city. They presented in detail the characteristics of Vilnius as of one the best smartly managed cities in the world and described the impact the smart environment has on the unbroken development of the city. The authors emphasize the need for educational movies (something quite novel both in Lithuania and the world at large) which combine informative contents with more appealing forms of interaction. Creating educational movies is to systematically contribute to the growth of smart environment as well as increases the use of smart city's innovations and the efficiency of a natural resource economization. The authors proposed to supply guidelines to indicate how to apply educational movies' perspectives in certain areas of smart cities.

\section{CREATIVE CITY THEORY AND PRACTICES}

The segment on Creative City Theory and Practices was chaired by Andrius Jonas Kulikauskas (Lithuania). The first presentation in this segment was "Cronotope of Creative City" by Ina Nalivaika 
(Belarusian State University, Minsk, Belarus) who asserted that a creative city can only exist as a unity of temporal and spatial dimensions where strategies of city authorities are supplemented by temporal everyday practices of the inhabitants. The view is based on Michel de Certeau's theory of a tactical character of everyday practices which confront official strategies by creatively appropriating them. Everyday tactics 'dwell' the space, planned by city's administration and architects, with the help of different temporal practices, penetrating the established borders. They create the so-called network of resistance to strategies imposed from outside and adapt the urban space to the needs of residents. As a result, the real city is a unity of different living chronotopes. The politics aimed at the cultivation of historical memory or at the preservation of cultural heritage as well as at development of tourism may be successful only if it correlates with these chronotopes. Moreover, it should regard the city itself as a unique chronotope.

Sharwan Kumar, Mukesh Kumar, and Rajinder Singh (CT Group of Institution, Jalandhar, India) presented "A Survey of Jaipur Metropolis Strategies as a Creative City of India". Jaipur metropolis is the political, economic and cultural capital of India and also has a huge training potential and a specific status in science and culture along with welfare facilities. It has a suitable background for elite attraction. Actually, Jaipur is a place for gathering creative people according to Florida's definitions. The existence of these specifications and the ability to enhance the indexes and standards of a creative city and also the codification of specific strategies could convert Jaipur to a creative city.

Liudmila Starostova, Larisa Piskunova (Ural Federal University, Russia), and Igor Yankov (Independent Researcher, Russia) spoke on "The Architecture of Constructivism: The Formation of Aesthetic Codes and Narratives". The authors presented a study of the architectural avant-garde of Sverdlovsk and showed that the weak perception by the inhabitants of the city's historical and cultural importance of constructivist buildings and complexes is associated not only with the lack of awareness but also with a low assessment of their aesthetic value. As it is known, constructivist architects paid a special attention to the functionality of the buildings rather than to their outward appearance. Meanwhile, the study of space-planning solutions for specific architectural projects reveals not those articulated by its creators but the really conceptual aesthetics of buildings. In addition, the study of the social history of constructivist architectural complexes, accepted by the authors, helped them to identify and articulate their cultural and historical significance and to highlight the visual perception of the marks of this architecture in the space of the city. The authors claim that a narrative approach to visually ambiguous architectural objects allows them to create a new urban optics, transforming an aesthetic value of architecture.

Ingrida Mažonavičiūtė, Romualdas Baušys, and Rokas Semėnas (VGTU) "Creative Way for Urban Projects Assessment by Gamified Survey”. Urban places like city parks are the living ecosystems where ecological, cultural, architectural and economic aspects must be accompanied by safety and attraction facets. Park development is the multifaceted process that sturdily affects the local society. An efficient communication among the government, communities and individual citizens is a crucial element to guarantee urban place sustainability. The presentation came up with an inventive method, which overcomes some issues of citizens' unwilling participation in urban projects estimation and aids to engage unmotivated citizens in the city park development process. The offline, GIS data based, three-dimensional gamified survey called "Attractive Park" was developed to gather civic insights about safety and attraction of the historical park called "Missioners' Gardens" (Vilnius, Lithuania). The proposed gamified offline survey is an emotionally immersive method, which helps to collect data that 
cannot be obtained by a classical questionnaire or a public consultation. Spatial data like trajectories of expected walking paths or coordinates of potentially insecure spaces and the most attractive places can be extracted in the early phases of the city park development process. The presented participatory method makes the urban project assessment appealing and decreases the bounce rate of classical surveys.

\section{CREATIVITY AND TOURISM}

The last session of 20 April was on Creativity and Tourism chaired by Ina Nalivaika (Belarus). It started with a co-presentation by Luis Pinto (Lusiada University of Lisbon and University of Beira Interior, Portugal), Antonio Polainas (Social Communication School, Portugal), and Artur Modlinski (Łódź University, Poland) - "Respect the Sacred Places in the Mass Tourism Context - An Audiovisual Perspective". The presentation was a reflection on the consequences of mass tourism in the holy places. Most of them are unaware of what they are seeing. Hence, they do not know how to respect each of these places. How to respect the sacred places? The authors offered a new way of looking at the subject, trying to see the problem from the perspective of communication - How can we communicate with people and demonstrate that the sacred spaces are much more than a place to take pictures? To do this, they suggested using the strategies, techniques and tools in the most efficient way of communicating our planet - that is, the audiovisual, using the audiovisual (video and audio) as a communication strategy and not as a simple tool, but as a concept and production. They suggested producing a story as a movie and play it through a living journey, sensory and emotional: so that tourists learn to read the place, and know what it has to communicate to them; it is to report to visitors how to feel and respect the space, to create a sharing relationship of knowledge in both directions.

Olga Mastianica (Institute of Lithuanian History, Lithuania), Rytė Žiūrienè, and Jekaterina Lavrinec (see also her other contributions 2013, 2014) (VGTU) in the presentation "Historical Research Meets Creative Tourism: Escape Rooms" explore the strategies of promoting creative tourism on the basis of historical research. They focussed on the materials of the historical research, devoted to the girls' gymnasiums in Vilnius in 19th century - the beginning of 20th century. Their central question was essential for building the bridges between academia and creative industries: how to turn the valuable research data into an attractive format for broad audience, including tourists? The presenters employed several concepts, one of which was non-formal learning that involves a wide range of creative approaches helpful to live through the historical experience. The next two were experience economy and creative tourism that promote alternative approaches toward tourist experience through active learning about the local context and through participation in local creative practices. To be precise, they explored the strategies of developing the creative product based on historical data, addressing it to various tourist groups.

Elena Sakalauskaitè (Lithuania) spoke on "Visual Communication in VR Projects - Tourism in Another Dimension". According to the presenter (more on her work see Sakalauskaite 2015), today VR technologies are getting more and more popular as they are becoming more and more available for the consumer to get. They range from more expensive ones such as the Oculus Rift, which costs a half thousand euros, to the Samsung gear, which costs less than a hundred, to the Google cardboard with just few euros in price, not to mention that sometimes some companies are just giving away cheap headsets for free as material, with also internet pages existing, where you can find instructions how to mount one yourself. This 
proves that VR projects are becoming more and more popular, extensively exploited for entertainment purposes, namely in games industry, 360 videos, spherical photos, etc. Just a few years ago spherical photos were such a novelty, and now there are many apps to make this. Also there are plenty of VR projects for educational and cultural purposes. Lithuania in this aspect is no exception. But even if VR projects are becoming more and more popular, there is a lack of articles to analyse its communicational aspects. The presenter seeks to fill this gap.

The first day of the conference was concluded by Jasz Borbala (Institute of Philosophy, Hungary) with the presentation "Mental Map of the City". With reference to Lewis Mumford's "The City in History" (1962), the presenter emphasized that the structure of modern cities is partially responsible for many social problems seen in the Western society. Urban planning should emphasize an organic relationship between people and their living spaces. The city is "a product of Earth, a fact of nature, man's method of expression". This organic approach to understanding cities is in connection with the theory of Kevin Lynch. In his The Image of the City (1960) there are 3 normative ways of the city planning theory distinguished: (1) the cosmic, (2) the mechanic and (3) the organic model. The author of the presentation chose to apply the onion model of culture (Hofstede 1991) for the city and its analysis. Then he examined the city with a special, architectural based mind map theory: the five elements by Kevin Lynch. According to Lynch, these five elements (paths, edges, districts, nodes, landmarks) create the mental map by readability. Third, the presentation investigated a usage of a mental map in modern city planning (Le Corbusier) and worked the process of 'debabelisation' (Neurath).

The second day of the conference started with a section on Urban Heritage chaired by Elena Sakaulauskaite (Lithuania). Luca Baraldi (Ibagué, Colombia) started it with his presentation "Emotional Landscapes: The Role of Intangible Heritage for Cultural Uniqueness". Luca's report focused on two aspects which represent key pillars of the creative city: 1) the process of community engagement as a form of democratic participation in the definition of emotional identity of the spaces; 2 ) the intangible heritage (mainly religions and folklore) as a dynamic opportunity for reflection on the interaction between memory and cultural transformation. The themes of cultural uniqueness and nation branding strategies can be a great tool for cultural diplomacy and enhancement of the potentialities of the territories, even if we have to prevent the risk of reducing the issue of branding strategies to a pure activity of destination marketing. The presentation suggested that we therefore identify the strengths for the protection of the true diplomatic value of local cultural ecosystems. The intangible heritage - based on social participation - is perhaps the most fragile element from the point of view of conservation, but more evocative from the point of view of the emotional impact of cultural identity.

Tomas Mitkus and Raimonda Steiblyte (VGTU) "Vilnius Heritage: Creativity and Work Culture of Soviet Film Industry 1975-1990”. In his papers (Mitkus, Nedzinskaitè-Mitkè 2016; Mitkus, Nedzinskaitè-Mitkè 2017), Mitkus analyses the film industry in its variety of aspects. Here, Mitkus and Steiblyte analysed the work environment in the Soviet Lithuanian film industry. Also, the evolution of ethical norms, principles and standards in the work environment of film industry in the 1975-1990 timeframe were analysed. They looked at primary sources (session memos, annual reports, professional film union's memos, etc.) and analysed what key elements influenced the work ethics of the Soviet Lithuanian film crew. According to the authors, findings suggest that the censorship, the tolerance of low work ethics and the strict annual production planning influenced the work environment that accepted a low film creative value and a negative attitude towards administration. 
The section on Virtual City and Urban Innovations was chaired by Ilya Inishev (Russia). The first ones to speak were Cláudia Beato, Perla Almeida (Universidade de Cabo Verde, Portugal), and Rafał Gładych (University of Science and Technology in Bydgoszcz, Poland): "Senses City: Tourism and Culture and Innovation". Speakers noted the meaning and relevance of the senses. Consciousness and thought unite in the creation of meanings through the articulation of sensory thoughts and responses, and in the storage of memories. Each of the five senses has a dominant characteristic - sight, for example, privileges the eye - so that each sense privileges its sensory organ. However, the senses work as a whole, and simultaneously, when it comes to perceiving an object, detaching in a dissociated way the strong side of each of the senses, allowing to create a total image. Thus, a permanent dialogue and a constant interaction with the environment is established, to the point that it is impossible to separate the ego image from its spatial and situational existence, where the human body is both an object in the midst of so many others and the object that sees them and touches them which allows them to be understood. In this sense the urban space and urban design options should invite the enjoyment of these senses, in a complex that should enhance the unique characteristics of the places.

Daiva Makutenienè (VGTU) delivered the presentation “The Analysis and 3D Modelling of Artefacts of Vilnius Cathedral". She took note that the design of the architectural details in the Vilnius Cathedral is very interesting on geometrical grounds. The analysis of geometry of the details of the interior inspired the idea about the database of $3 \mathrm{D}$ models of the artefacts at the Vilnius Cathedral. There are several ways to model these details - like solid models, or parametric models. The presenter described some differences for modelling by various CAD systems and methods. Analysis was made to examine the created database of the details geometry at first. Some problems about 3D printing were also analysed. She was going to use these models in her work with students in the Architecture Faculty.

\section{ETHICAL ISSUES OF URBAN STUDIES}

The conference was concluded with a discussion on Ethical Issues of Urban Studies chaired by Daiva Makutènienè (Lithuania).

Basia Nikiforova (Lithuanian Culture Research Institute, Lithuania) "Representations of the Refugee: Imaging the Unimaginable". The author is known for her papers on religious studies (Nikiforova 2017) as well as on visuality studies (Nikiforova 2015). The author analysed the European public discourse and visual images of migrants in the mass media using a visual and critical discourse analysis. The presentation included virtual imaging of refugees as a sociological site. Methodological approaches to the intersection between mobility and security and its visual image were discussed. A border is a place where "past" and "future" are permanently clashed. In the new materialists" view, the "past" is open to change. History suggests that borders and borderlands are territories where a possibility to "repair" the "now" situation exists (Karen Barad, Donna Haraway). This kind of "diffraction patterns" are not simply reflections, they are not reflected in a specific place, instead, they produce changes in public consciousness. The massive ongoing refugee crisis in Europe is an example of such kind of diffraction, which, in reality, not only is a concentration of current wars and conflicts, but also represents the "past" long history of injustice and political mistakes. In an increasingly diasporic world borders are de-territorializated, but nowadays Europe is a space of real and imagined encounters for migrants, traffickers, policemen and host citizens. In fact, an external border is the tangible reality for all of the involved in this process and has become "a new normality". The nowadays meaning of European external borders includes survival, 
resistance and an attempt to escape from the armed conflicts, ongoing violence, persecution and instability in origin countries, ecological disasters and economic difficulties.

Andrius Kulikauskas (Vilnius Gediminas Technical University, Lithuania) "Moral Imagination: What Do We Wish to See? Soviet Sports Palace vs. European Convention Center vs Historic Jewish Cemetery". The presenter considered how a specific symbol (image, word, etc.) can become the answer to a complicated social question representing many distinct concerns, concepts and points of view. He analysed the hierarchy of interests at play in Vilnius regarding the future of the decrepit Soviet-era Sports Palace. He noted that EU and Lithuanian government funds are available to remake it as a convention center. This would be the most straightforward outcome. However, the Soviets constructed the Sports Palace in the middle of Vilnius's oldest Jewish cemetery. This becomes an issue of sensitivity to what we imagine, what is actually the case, what we will ultimately see, and what that image might imply, symbolize, sanction, condemn or have us imagine anew. Will local Lithuanians and European tourists be celebrating, drinking and urinating over the remains of Lithuania's Jews? What remains are left and do the facts actually matter? The Lithuanian government came to agreement with the Jewish Community of Lithuania and with London-based rabbis which allowed reconstruction to proceed. But opposition has arisen among Jews locally and internationally. Kulikauskas presented a semiotic analysis of this debate. A sign may enrich our self-identity with a solution that summarizes a hierarchy of concerns.

Ilze Grinfelde and Linda Vaeliverronen (Vidzeme University of Applied Sciences, Latvia) concluded the conference with their presentation "Conducting an Orchestra of Emotions in the Darkness". The authors explained that the post-soviet heritage is a specific feature of many cities in Eastern Europe and one such heritage site is the KGB Building that functions as a museum of the Communist regime victims in Riga, Latvia. The integration of objects like that in a contemporary city environment and tourism is not related just to physical but also to psychological issues. Recently, however, the situation has been improved markedly as many sites have been recognized as heritage that could be utilized in tourism. Nevertheless, there are still only a few cases where a particular 'unwanted' heritage has been packed as a tourism product. The study results claimed that this kind of dark tourism is meaningful for visitors and it becomes sensible not only through new knowledge, but also by experiencing various emotions during the visit. However, measuring emotions in dark tourism sites is a methodologically challenging task.

The conference was celebrated by a tour to the ancient Trakai Castle guided by Stanislavas Dadelo (Lithuania).

\section{FINAL REMARKS}

The Visuality conference has taken place every two years and this year's conference which focused on the issue of tourism versus heritage in the creative city enjoyed a particular success. Hence, the plan for the next international conference in two years has already been developed.

Participants from various parts across the globe enjoyed the conference - from Portugal to Russia, from the USA to India, from Colombia to Hungary, etc. Presentations were either delivered by a single author or co-authored. Each of them contributed with a unique point of view, and a wide range of issues both theoretical and practical were discussed. A great deal of methods or approaches were proposed. The ample research on the ways to deal with city heritages as well as to develop cities in novel ways which also respond to challenges of a wide-spread tourism has proven to be available. Useful international connections between researchers were established. 


\section{References}

1. Florida, R. 2015. Kürybinès klasès iškilimas. Vertè J. Barevičiūtè. Vilnius: Technika.

2. Kačerauskas, T. 2008. „Gyvenimas šiapus ir anapus ekrano" [Life on This Side and the Other Side of the Screen], Filosofija. Sociologija 19(1): 18-25.

3. Kačerauskas, T. 2012. "Creative Economy and Technologies: Social, Legal and Communicative Issues", Journal of Business Economics and Management 13(1): 71-80.

4. Kačerauskas, T. 2010. „Matymas, žiūra ir vaizdijimas: egzistencinès sąveikos“ [Seeing, Viewing and Imagination: Existential Interactions], Filosofija. Sociologija 21(1): 11-19.

5. Kačerauskas, T. 2014. „Kūrybos ekonomikos sektoriai: kūrybinių industrijų sąrašų lyginamoji analize“" [The Sectors of Creative Economy: A Comparative Analysis of Different Lists of Creative Industries], Filosofija. Sociologija 25(1): 35-43.

6. Kačerauskas, T. 2015. "Technologies in Creative Economy and Creative Society”, Technological and Economic Development of Economy 21(6): 855-868.

7. Landry, C. 2000. The Creative City: A Toolkit for Urban Innovators. London: Earthscan Publications.

8. Lavrinec, J. 2013. "Urban Scenography: Emotional and Bodily Experience", Limes: Borderland Studies 6(1): 21-31.

9. Lavrinec, J. 2014. "Community Art Initiatives as a Form of Participatory Research: The Case of Street Mosaic Workshop", Creativity Studies 7(1): 55-68.

10. Mickūnas, A. 2017. "Resistance to Western Popular and Pop-culture in India", Santalka: filosofija, komunikacija 25: 48-62.

11. Mickūnas, A. 2016. “The Different Other and Dialogue”, Santalka: filosofija, komunikacija 24(1): 3-13.

12. Mickūnas, A. 2015. "Discourses and Inter-corporeity", Santalka: filosofija, komunikacija 23(2): 109-123.

13. Mitkus, T.; Nedzinskaitè-Mitkè, V. 2016. "The Impact of Globalization to Creative Industries: The Analysis of Film Industries of Central and Eastern Europe", Creativity Studies 9(1): 64-74.

14. Mitkus, T.; Nedzinskaitè-Mitkè, V. 2016. "Promoting Competetiveness in Creative Industries: Changes and Trends of Lithuanian Film Industry in 21st Century", Creativity Studies 10(1): 14-25.

15. Nikiforova, B. 2017. "Cultural and Religious Dimensions of the Sacred and Profane Ambivalence: The Vilnius Case", Studies in East European Thought 69(2): 153-164.

16. Nikiforova, B. 2015. "Philosophy of Matter Manipulation in Brothers Quay' Metaphirical Animation World”, Creativity Studies 8(1): 3-11.

17. Petsu, T.; Mester, B. 2016. "Hungarian Philosophy in the Context of the European Philosophy", Hermeneia 16: 151-159.

18. Sakalauskaite, E. 2015. "Augmented Reality as Means of Travel - When Picture Changes Place", Creativity Studies 8(2): 95-102.

VITALIJA KECIORYTĖ, NERIJUS STASIULIS

\section{Vizualumas 2017: turizmas $v s$ paveldas kūrybiniame mieste}

Santrauka

Straipsnyje apžvelgiame ketvirtąją tarptautinę mokslinę konferenciją „Vizualumas 2017: paveldas $v$ s turizmas kūrybiniame mieste“. Pateikiame konferencijos eigą ir pranešèju idejas, apimančias ịvairias, bet susietas temas. Konferencijoje kūrybiniam miestui iškylančios problemos aptartos tiek plačiu teoriniu, tiek konkrečiais praktiniais požiūriais. Pavyzdžiui, vyko praktiniai (politiniai, kasdieniniai) debatai teorinių analizių ir naujoviškų požiūrių ị multimedijų technologijas klausimais, jų vaidmenį siekiant sukurti patrauklesnį ir prieinamesnį kūrybinį miestą. Pasiūlyta (arba aptarta) skirtingų kūrybiško buvimo mieste ir žvelgimo ị jị būdų.

Raktažodžiai: kūrybinis miestas, multimedijų technologijos, paveldas, turizmas, vizualumas 